Article

\title{
The Quality of Carrot after Field Biostimulant Application and after Storage
}

\author{
Jarosław Pobereżny ${ }^{1}$, Małgorzata Szczepanek ${ }^{2, *} \mathbb{C}$, Elżbieta Wszelaczyńska ${ }^{1}$ and Piotr Prus ${ }^{3}$ \\ 1 Institute of Microbiology and Food Technology, Faculty of Agriculture and Biotechnology, UTP University of \\ Science and Technology, Kaliskiego 7 str., 85-796 Bydgoszcz, Poland; poberezny@utp.edu.pl (J.P.); \\ wszela@utp.edu.pl (E.W.) \\ 2 Department of Agronomy, Faculty of Agriculture and Biotechnology, UTP University of Science and \\ Technology, Kaliskiego 7 str., 85-796 Bydgoszcz, Poland \\ 3 Laboratory of Economics and Counseling in Agribusiness, Department of Agronomy, Faculty of Agriculture \\ and Biotechnology, UTP University of Science and Technology in Bydgoszcz, Fordońska 430 str., \\ 85-790 Bydgoszcz, Poland; piotr.prus@utp.edu.pl \\ * Correspondence: malgorzata.szczepanek@utp.edu.pl; Tel.: +48-52-374-94-65
}

Received: 28 December 2019; Accepted: 12 February 2020; Published: 13 February 2020

\begin{abstract}
The carrot (Daucus carota L.) is a staple vegetable in human nutrition in Europe. In recent years, the use of biostimulants in vegetable crops has become a way to affect the quantity and quality of yields. The aim of this study was to assess the effect of the type and methods of biostimulant (natural seaweed extract Kelpak and synthetic Asahi) application on the nitrates and nitrites content in carrot roots after harvest and storage. The study was based on a strict field experiment with carrot cv. 'Karotan', conducted in Poland $\left(53^{\circ} 13^{\prime} \mathrm{N} ; 17^{\circ} 51^{\prime} \mathrm{E}\right)$ in three successive growing seasons and after six months of storage ( $\mathrm{RH} 95 \%$, and air temperature $+1{ }^{\circ} \mathrm{C}$ ). The biostimulants were applied during the growing season in a foliar form. The content of $\mathrm{NO}_{3}{ }^{-}$and $\mathrm{NO}_{2}{ }^{-}$in carrot after harvest depended on the dose and the date of biostimulant application. The single application of biostimulant Kelpak as well as two times of Asahi had no effect on the nitrate and nitrite content, while the application of Kelpak in a total dose of 6 or $7 \mathrm{dm}^{3} \mathrm{ha}^{-1}$ increased them. The maximum intake of nitrates and nitrites following the harvest and storage was, respectively, $7.1,2.3 \%$ and $6.7,2.1 \%$ of the ADI.
\end{abstract}

Keywords: anti-nutritive compound; biostimulant; long-term storage; nitrate; nitrite; seaweed extract

\section{Introduction}

In recent years, agricultural biological includes biofertilizers, biopesticides and biostimulants have gained higher importance over the synthetic farm inputs. Biostimulants are among some of the earliest agricultural inputs used by humanity and are an important component of sustainable agricultural practices [1-6]. According to the EU regulation (2019/1009) [7]: "plant biostimulant is a product stimulating plant nutrition processes independently of the product's nutrient content with the sole aim of improving one or more of the following characteristics of the plant or the plant rhizosphere: (a) nutrient use efficiency; (b) tolerance to abiotic stress; (c) quality traits; (d) availability of confined nutrients in soil or rhizosphere". Rising demand for high-value crops and increasing abiotic soil and plant stresses encourage farmers to adopt bio-based agriculture products such biostimulants that can increase the crop yield and its quality. Increasing governmental support to high-quality agricultural product and launch of programs to educate farmers about various eco-friendly agri-input products use in farming [8-11] are some of the crucial reasons that are projected to enhance the biostimulants' market growth during forecast years. Moreover, increasing product launches by market players and increased focus on novel substances that can potentially act as biostimulants are anticipated to aid 
growth. The global biostimulants market size was valued at USD 2.25 billion in 2018 and is projected to reach USD 5.69 billion by the end of 2026, exhibiting CAGR of 12.4\% in the forecast period (2019-2026). In the global biostimulants market, the most important are humic substances and seaweed extracts [12]. In 2017, Europe (a region which has a high market demand for vegetables, including carrots) accounted for $40.2 \%$ of the total demand of the biostimulant market. A further increase in the use of biostimulants is forecasted in this region [12].

Biostimulants are intended not only to protect plants against the abiotic factors and also to facilitate the regeneration of stress-induced changes [13-15]. The biostimulation effect under both optimal and suboptimal conditions could be attributed to mechanisms including more vigorous root system (higher root biomass, surface area and number of lateral roots), especially in crops having a taproot system (e.g., carrot). A better developed root system lead to the efficient utilization of available nutrients [16,17]. Biostimulants affect physiology of the plant (global transcriptome and the metabolome). Recent research involving gene expression analyses is shedding light on plants' metabolic regulatory pathways that are specifically affected by seaweed extracts $[18,19]$. Their performance is determined not only by weather conditions [13,20,21] but also by the date and the applied dose [20,22-24]. Biostimulants are commonly used in agricultural crops and vegetables. Plant raw materials are an essential in the human diet and carrot (Daucus carota L.) is one of the most frequently consumed. The year-round availability of carrots results from high fertility and good storage life. The storage roots of carrots are also an excellent raw material for the processing industry. They are used for the production of juices, frozen products, dehydrated products and preserved carrots [25-27]. The quality of carrot roots is determined by numerous factors, including cultivar, environmental conditions, cultivation method and storage technology $[24,26,28-30]$. The carrot is a vegetable which is very prone to the accumulation of nitrates and nitrites. The average nitrate content in carrots is $200 \mathrm{mg} \mathrm{kg}^{-1} \mathrm{FW}$ [26,29,31-33]. Nitrate itself is relatively harmless since the fatal adult dose is considered to be higher than 7-35 $\mathrm{g}$, which is about 100-fold higher than the acceptable daily intake of $\mathrm{NO}_{3}{ }^{-}$set by the European Union $\left(3.7 \mathrm{mg} \mathrm{kg}^{-1} \mathrm{body}\right.$ weight per day, equivalent to $222 \mathrm{mg}$ of $\mathrm{NO}_{3}{ }^{-}$per day for a $60 \mathrm{~kg}$ individual [34]. According to the Polish Norms, the content of nitrates in carrot should not exceed $400 \mathrm{mg} \mathrm{kg}^{-1}$ in fresh weight, and in the carrot allocated to processed foods for children below 3 years of age, only $200 \mathrm{mg} \mathrm{kg}^{-1}$ in fresh weight [32]. This is of importance as carrots are a basic component of the diet and the nitrates supplied with vegetables account for $70-90 \%$ of the daily amount $[24,32,34]$. It should also be noted that carrots are an important raw material for many products used in child nutrition. In this case, it must meet the highest quality standards in the food industry [35]. The occurrence of undesirable substances, inter alia nitrates, in food poses a high risk to consumer safety [36-38]. High level of nitrate can be accumulated in vegetables, as indicated in the EU regulation (1258/2011) [39]. The adverse effect of nitrates on a consumer results from the fact that in the alimentary system they are transformed, under the influence of digestive enzymes, into nitrites and then into carcinogenic N-nitro compounds. The harmfulness of nitro compounds results from the oxidation of hemoglobin to methemoglobin. They also have a destructive effect on vitamins of the A and B groups as well as on carotenoids [33,40,41]. On the other hand, research results can be found proving that nitrates can have beneficial effects for human health as well [42].

Modern technologies of carrot production use a number of agricultural production means supporting yields and quality of crops, including biostimulants. The use of biostimulants in the cultivation of carrots leads to an increase in the produced biomass; however, it can modify the chemical composition of roots $[14,23,24,32]$. Yet, it is not known whether the use of biostimulators in different doses and dates in field production does not pose a threat to food safety, especially for long-term stored raw materials. The aim of this study was to determine the effects of the biostimulant application methods as well as long-term storage on nitrates and nitrites content in the storage roots of carrots. 


\section{Materials and Methods}

\subsection{Field Experiment}

The research material was provided from field experiments performed at the Experiment Station in Mochełek ( $53^{\circ} 13^{\prime} \mathrm{N} ; 1^{\circ} 51^{\prime} \mathrm{E}$ ), belongs to the UTP University of Science and Technology in Bydgoszcz (Poland). These experiments were carried out in light soil with mean richness in available P and $\mathrm{K}$ forms, very low Mg richness, and a slightly acid reaction. More details on soil characteristics can be found in Szczepanek et al. [23]. Weather conditions at the experimental site are presented in Table 1. Of all the research years (2009-2011), the year 2011 was most favorable. The year which was less favorable for carrot growth was 2010, with a drought in June, while the year 2009 with high precipitation from May to July, accompanied by low air temperature and drought at the end of the growing period of carrot (August and September) was least favorable.

Table 1. Meteorological data at the experimental site.

\begin{tabular}{ccccccccc}
\hline \multirow{2}{*}{ Month } & \multicolumn{3}{c}{ Precipitation $(\mathbf{m m})$} & \multicolumn{3}{c}{ Air Temperature $\left({ }^{\circ} \mathbf{C}\right)$} \\
\cline { 2 - 9 } & $\mathbf{2 0 0 9}$ & $\mathbf{2 0 1 0}$ & $\mathbf{2 0 1 1}$ & $\mathbf{1 9 4 9 - 2 0 1 1}$ & $\mathbf{2 0 0 9}$ & $\mathbf{2 0 1 0}$ & $\mathbf{2 0 1 1}$ & $\mathbf{1 9 4 9 - 2 0 1 1}$ \\
\hline April & 16.3 & 33.8 & 13.5 & 27.4 & 11.5 & 7.8 & 10.5 & 7.4 \\
May & 85.3 & 92.6 & 38.4 & 43.2 & 12.3 & 11.5 & 13.5 & 12.7 \\
June & 57.4 & 18.1 & 100.8 & 53.7 & 14.5 & 16.7 & 17.7 & 16.3 \\
July & 118.0 & 107.4 & 132.5 & 73.1 & 18.6 & 21.6 & 17.5 & 18.0 \\
August & 17.6 & 150.7 & 67.7 & 53.2 & 13.2 & 18.4 & 17.7 & 17.5 \\
September & 34.4 & 74.7 & 37.0 & 41.1 & 13.7 & 12.2 & 14.3 & 13.2 \\
\hline
\end{tabular}

In our study, mid-late cultivar 'Karotan' of carrot (Daucus carota L.) was used. Pre-sowing fertilization was applied; with nitrogen $(\mathrm{N})$ at the rate of $60 \mathrm{~kg} \mathrm{ha}^{-1}$, phosphorus (P) $30.6 \mathrm{~kg} \mathrm{ha}^{-1}$ and potassium (K) $66.4 \mathrm{~kg} \mathrm{ha}^{-1}$. Seed sowing was performed in the first decade of April, with the seed sowing rate of $4 \mathrm{~kg} \mathrm{ha}{ }^{-1} 2 \mathrm{~cm}$ deep, at the row spacing of $30 \mathrm{~cm}$. The seeds were provided with Marshal 250 DS seed dressing. The next treatments of plant protection from diseases and pests complied with carrot requirements. After sowing and before carrot emergence, Afalon Dyspersyjny $450 \mathrm{SC}$ herbicide was applied $\left(1.5 \mathrm{dm}^{3} \mathrm{ha}^{-1}\right)$, while at the 3-leaf phase Linurex $500 \mathrm{SC}$ was provided $\left(1.5 \mathrm{dm}^{3} \mathrm{ha}^{-1}\right)$. During the vegetation period, manual weed control was made. The carrot storage roots were harvested at full maturity (the 3rd decade of September).

A single-factor field experiment applied a randomized block design in four replications and single-plot area was $13 \mathrm{~m}^{2}$. The experimental design covered biostimulant application kind and methods are presented in Table 2. Kelpak was applied in a form of foliar application, having been dissolved in $300 \mathrm{dm}^{3}$ of water per hectare at the total rate of: $0,2,3,4,5,6$ and $7 \mathrm{dm}^{3} \mathrm{ha}^{-1}$. Asahi was also applied as a foliar treatment, having been dissolved in $500 \mathrm{dm}^{3}$ of water per hectare, at the concentration of $0.1 \%$. Kelpak is a completely natural biostimulant produced from seaweed Ecklonia maxima (Osbeck) which contains auxins $\left(11 \mathrm{mg} \mathrm{dm}^{-3}\right)$ and cytokinins $\left(0.03 \mathrm{mg} \mathrm{dm}^{-3}\right)$, alginate, amino acids (Histidine, Serine, Arginine, Aspartic acid, Glutamic acid), as well as small amounts of macro and microelements [33] (N 0.09\%, and P 90.7; K 7163.3; Ca190.4; Mg 337.2; Na $1623.7 \mathrm{mg}$ $\mathrm{kg}^{-1}$ fresh weight) [43]. However, Asahi is based on the nitrophenols-derivatives group compounds (para-nitrophenol (PNP) sodium salt $0.3 \%$, sodium ortho-nitrophenol (ONP) sodium salt $0.2 \%$ and 5-nitroguaiacol sodium salt (5NG) $0.1 \%$, and their effect is an increase in the content of chlorophyll in leaves and the intensity of photosynthesis, growth and development support as well as counteracting a fast plant ageing [44]. 
Table 2. Field experimental treatments.

\begin{tabular}{cccc}
\hline \multirow{2}{*}{ Biostimulant } & \multicolumn{3}{c}{ Date and Rate of Biostimulant Application $\left.\mathbf{( d m}^{\mathbf{3}} \mathbf{h a}^{\mathbf{1}}\right)$} \\
\cline { 2 - 4 } & $\begin{array}{c}\text { 1st Applicationin } \\
\text { 4-Leaf Phase }\end{array}$ & $\begin{array}{c}\text { 14 Days After } \\
\text { 1st Application }\end{array}$ & $\begin{array}{c}\text { 28 Days After 1st } \\
\text { Application }\end{array}$ \\
\hline Control & - & - & - \\
Kelpak 1 & 3 & - & - \\
Kelpak 2 & 2 & - & - \\
Kelpak 3 & 3 & 2 & - \\
Kelpak 4 & 2 & 2 & - \\
Kelpak 5 & 3 & 2 & 2 \\
Kelpak 6 & 2 & 2 & 2 \\
Kelpak 7 & 3 & - & 2 \\
Kelpak 8 & 2 & - & 2 \\
Asahi & 0.5 & 0.5 & - \\
\hline
\end{tabular}

\subsection{Storage Conditions}

The harvest was conducted at full physiological carrot maturity and root samples $(10 \mathrm{~kg})$ were taken for storage from each plot. The roots were then stored in chambers. A constant temperature $(+1 \mathrm{C})$ and relative air humidity $(95 \%)$ were then maintained over six months of storage, according to the requirements of carrots.

\subsection{Laboratory Analysis Procedure}

The plant samples (carrot roots) were purified and foreign substances (which included soil and dust particles) were then removed. Then the samples were cut into 1-cm-thick slices and freeze-dried (CHRIST ALPHA 1-4 LSC, Germany). The product was lyophilized to permanent weight with a moisture content $<2 \%$, and then was crushed into fine powder using an electric grinder (CHEMLAND, Type FW 177, Poland). The obtained samples were stored in sealed plastic bags at $-20{ }^{\circ} \mathrm{C}$ and then were used for a chemical analysis.

The contents of nitrates and nitrites were then determined both directly after harvest and after six months of storage using the ion-selective method [45]. A multi-purpose Elmetron CX-721 computer was used which was equipped with a nitrate electrode, double junction reference electrode (fill outer chamber with $0.02 \mathrm{M}\left(\mathrm{NH}_{4}\right)_{2} \mathrm{SO}_{4}$ solution; Merck, Germany) and specific ion meter and a $\mathrm{pH} / \mathrm{millivolt}$ $(\mathrm{mV})$ meter with a $0.1 \mathrm{mV}$ readability. Nitrates were extracted using a $\mathrm{KAl}\left(\mathrm{SO}_{4}\right)_{2}$ (Merck, Germany) solution and determined potentiometrically by an ion-selective electrode. Two grams of freeze-dried carrots and $50 \mathrm{~cm}^{3} 1 \%$ of $\mathrm{KAl}\left(\mathrm{SO}_{4}\right)_{2}$ extracting solution were then mixed and shaken (IKA KS 130 BASIC, Germany) for one hour. Subsequently, $10 \mathrm{~cm}^{3} \mathrm{Al}_{2}\left(\mathrm{SO}_{4}\right)_{3}$ was added (Acros Organics, USA) to it and shaken immediately before the analysis.

The standard solutions were all conducted in the $0.025 \mathrm{M} \mathrm{Al}_{2}\left(\mathrm{SO}_{4}\right)_{3}$ background solution and de-ionised water was also used in the analytical research at each stage of the analysis. The total content of $\mathrm{NO}_{2}{ }^{-}$ions was determined after oxidation to $\mathrm{NO}_{3}{ }^{-}$in a previously prepared sample of this extract according to the method described above. An amount of $1 \mathrm{~cm}^{3}$ of $30 \% \mathrm{H}_{2} \mathrm{O}_{2}$ (Merck, Germany) was added and the ion-metric potential was carefully measured after five minutes in order to facilitate the oxidation of $\mathrm{NO}_{2}{ }^{-}$to $\mathrm{NO}_{3}{ }^{-}$. The anti-nutritive compounds (nitrate and nitrite) concentration in fresh mass was calculated taking into account the $\mathrm{H}_{2} \mathrm{O}$ content in the carrot roots.

\subsection{Statistical Analysis}

The 3-year research results were statistically verified applying the method of the analysis of variance for single experiments in each year of the study (2009, 2010 and 2011) and the synthesis from the years. The significance of differences was evaluated using Tukey's HSD test for the significance level of $\alpha=0.05$. Analysis of variance (ANOVA) of the data was computed using the Statistica ${ }^{\circledR}$ 
13.1 Computer Program (StatSoft Inc., TIBCO Software Inc., Palo Alto, CA, USA). In our study, weather conditions in study years did not have a significant impact on the content of nitrates and nitrites in roots; therefore, only average values for nitrates and nitrites are presented. The coefficient of correlation was calculated using Spearman's rank order at $\mathrm{P}<0.05$. The daily intake of nitrates and nitrites was determined assuming the consumption of $55 \mathrm{~g}$ of fresh carrot per person (average consumption of fresh and processed carrot (without juice) is $20 \mathrm{~kg} \mathrm{year}^{-1}$ per person in Poland). The data were compared with the norms (JECFA 2002) considering the Acceptable Daily Intake (ADI) by an adult (weight 60 $\mathrm{kg}$ ), which equals to $222 \mathrm{mg} \mathrm{day}^{-1}$ of nitrates, and $4.2 \mathrm{mg} \mathrm{day}^{-1}$ of nitrites [34,46].

\section{Results and Discussion}

\subsection{Nitrate Content}

The results of tests determining nitrate content of the carrot roots are presented in Table 3. Data on the accumulation of nitrates in the vegetables, provided in the literature [26,34], vary considerably as the contents range from 0 to $3000 \mathrm{NO}_{3}{ }^{-} \mathrm{mg} \mathrm{kg}^{-1}$ and even up to $9000 \mathrm{mg} \mathrm{kg}^{-1}$ in the fresh weight (FW) of the roots. In our study, irrespective of the experimental factors, nitrate content following the harvest was, on average, $255 \mathrm{mg} \mathrm{kg}^{-1} \mathrm{FW}$. The average contents of nitrates at levels similar to that in our study were obtained by Sušin et al. [26] 264, and by Karkleliene et al. [29] $249 \mathrm{mg} \mathrm{kg}^{-1} \mathrm{FW}$. In studies by Grudzińska and Zgórska [47] and Ziarati and Arbabi-Bidgoli [27], the contents of this harmful compound were at a much higher level and amounted to $459 \mathrm{mg} \mathrm{kg}^{-1} \mathrm{FW}$.

Many authors have indicated that the most important factor affecting the content of nitrates in the carrot is the genetic liability to accumulate in the roots $[32,35,48,49]$. In the current study, nitrate contents in the roots of cv. 'Karotan' ranged from 224 to $286 \mathrm{mg} \mathrm{kg}^{-1} \mathrm{FW}$. Gajewski et al. [35] examined two varieties of orange-coloured carrots and obtained a nitrate content ranging from 223 to $325 \mathrm{mg}$ $\mathrm{kg}^{-1} \mathrm{FW}$, with the cv. 'Karotan', exhibiting a greater accumulating tendency than the 'Trafford' variety. On the other hand, Wszelaczyńska et al. [32], while performing tests on five varieties, obtained nitrate contents ranging from 49 to $218 \mathrm{mg} \mathrm{kg}^{-1} \mathrm{FW}$, and in the roots of cv. 'Karotan', the nitrate content was $234 \mathrm{mg} \mathrm{kg}^{-1} \mathrm{FW}$. Anyszka and Elkner [50], and Dobrzański et al. [51], obtained nitrate content at a considerably lower level, i.e., $162 \mathrm{mg} \mathrm{kg}^{-1} \mathrm{FW}$. It follows from both our own previous studies and those by other authors that the nitrate content of the carrot is also contributed to by the applied cultivation technology $[20,32,48]$.

Table 3. Nitrates content in carrot storage roots depending on the type and methods of biostimulant application and the time of storage, mean 2009-2011 ( $\left.\mathrm{mg} \mathrm{kg}^{-1} \mathrm{FW}\right)$.

\begin{tabular}{ccccc}
\hline Biostimulant & After Harvest & CV (\%) & After Storage & CV (\%) \\
\hline Control & $223.7 \pm 10.3 \mathrm{a}$ & 4.62 & $215.7 \pm 10.1 \mathrm{a}$ & 4.68 \\
Kelpak 1 & $241.0 \pm 4.0 \mathrm{abc}$ & 1.65 & $226.0 \pm 10.4 \mathrm{a}$ & 4.59 \\
Kelpak 2 & $248.0 \pm 5.8 \mathrm{abc}$ & 2.33 & $232.8 \pm 9.5 \mathrm{ab}$ & 4.10 \\
Kelpak 3 & $250.3 \pm 13.4 \mathrm{abc}$ & 5.37 & $241.4 \pm 17.4 \mathrm{ab}$ & 7.20 \\
Kelpak 4 & $256.1 \pm 19.3 \mathrm{abc}$ & 7.52 & $246.9 \pm 25.4 \mathrm{ab}$ & 10.30 \\
Kelpak 5 & $286.0 \pm 14.5 \mathrm{c}$ & 5.07 & $268.7 \pm 15.9 \mathrm{~b}$ & 5.92 \\
Kelpak 6 & $272.6 \pm 16.5 \mathrm{bc}$ & 6.06 & $238.0 \pm 3.5 \mathrm{ab}$ & 1.46 \\
Kelpak 7 & $268.3 \pm 29.8 \mathrm{bc}$ & 11.12 & $246.5 \pm 38.1 \mathrm{ab}$ & 15.44 \\
Kelpak 8 & $265.2 \pm 17.36 \mathrm{bc}$ & 6.51 & $233.7 \pm 21.7 \mathrm{ab}$ & 9.30 \\
Asahi & $235.0 \pm 31.61 \mathrm{abc}$ & 1.47 & $225.8 \pm 5.1 \mathrm{a}$ & 2.26 \\
\hline Total mean & $254.6 \pm 22.3$ & 8.75 & $237.5 \pm 21.0$ & 8.82 \\
Biostimulants mean & $258.0 \pm 20.5$ & 7.96 & $240.0 \pm 20.5$ & 8.55 \\
Kelpak mean & $260.9 \pm 20.0$ & 7.65 & $241.7 \pm 21.1$ & 8.72 \\
\hline
\end{tabular}

Means sharing the same letter in column are not significantly different from each other (Tukey's significant difference test, $\mathrm{P}<0.05)$. CV means the coefficients of variation. Data were presented as the means \pm standard deviations $(\mathrm{n}=18)$. 
In our study, significant differences in nitrate content after harvest of the carrot were obtained, which depended on the dose and the date of biostimulant application (Table 3). The single application of biostimulant Kelpak ( $\mathrm{K} 1$ and $\mathrm{K} 2$ ), and two times application in early growing stages of carrot (K3 and K4) did not affect the nitrate content. Similarly, no influence of biostimulant Asahi on this anti-nutritive component in carrot storage roots was observed. According to our earlier study, the single application of biostimulant Kelpak was also favorable for carrot roots yield [23]. The best results in increasing the commercial yield were achieved after the application of Kelpak at doses of 2 or $3 \mathrm{dm}^{3} \mathrm{ha}^{-1}$ at the fourth-leaf stage (13.1\% and $12.4 \%$ respectively, compared to the control). Moreover, the application of biostimulant Kelpak in a dose of $2 \mathrm{dm}^{3} \mathrm{ha}^{-1}$ at 4-leaf phase resulted in the significant increase of vitamin $C$, carotenoids, total sugars, and reducing sugars [24]. In the same treatment, the highest concentration of $\mathrm{Mg}, \mathrm{P}, \mathrm{Na}$ and $\mathrm{K}$ in roots has been shown, while the highest content of $\mathrm{Ca}$ was after the application of this biostimulant in a dose of $3 \mathrm{dm}^{3}$ per ha. On the other hand, the application of Asahi did not affect the $\mathrm{Mg}, \mathrm{P}, \mathrm{Ca}$ and $\mathrm{Na}$ concentrations but similarly to Kelpak, increased content of K [52].

The impact of biostimulants on nitrate content in carrot is ambiguous. Smolen et al. [53] claimed that biostimulant application can result in a reduction in nitrate content which results from the amino acids and growth regulators contained in some preparations. They transport nutrients (particularly micronutrients) through the leaves to the plant and are a building material for proteins. Dobrzański et al. [51], by applying preparations AlgaminoPlant and HumiPlant, obtained a reduction in nitrate content in roots. Following the simultaneous application of both preparations, they obtained a 37\% reduction in nitrate content, while following the application of AlgaminoPlant only a $15 \%$ reduction. In the study by Kwiatkowski et al. [54], the reduction of nitrate content in carrot roots (by 12-18\%) after application of biostimulant (Asahi, Bio-algeen and Tytanit) has been presented.

In this study, the application of Kelpak several times (K5, K6, K7 and K8) resulted in an increase in nitrate content. It should be noted that the increase in nitrate levels was mainly contributed to by an increase in the dose of Kelpak to $7 \mathrm{dm}^{3} \mathrm{ha}^{-1}$ with a simultaneous increase in the number of application dates to three; however, its action was determined to a greater extent by the dates of application than by the doses. This was confirmed by the calculated variation coefficients (Table 2). In a study by Przybysz et al. [21], the applied biostimulants significantly increased the $\mathrm{NO}_{3}{ }^{-}$content in the plant's materials. Similarly, Wierzbowska et al. [15], following the application of Asahi, obtained a higher nitrate content in the carrot roots than in the control. According to Grabowska et al. [14], plants sprayed with Aminoplant (amino acidic solution derived from hydrolyzed animal proteins) were characterized by a higher nitrates content as compared to the control only in the study year, when the average concentration of nitrates in roots was relatively high $\left(375 \mathrm{mg} \mathrm{kg}^{-1} \mathrm{FW}\right)$.

After storage, a reduction of nitrate content in carrot roots was obtained (Table 3). This is beneficial for a consumer. The content of nitrates in carrot roots after six months of storage was dependent on the biostimulant type and method of its applications. The concentration of nitrates in roots was higher after the highest dose of seaweed extract Kelpak $\left(7 \mathrm{dm}^{3} \mathrm{ha}^{-1}\right)$ than after the dose of $3 \mathrm{dm}^{3} \mathrm{ha}^{-1}$ (K1) or after application of Asahi and in the control. The obtained increase in nitrate levels in roots (after harvest and storage) in our study under the influence of biostimulants applied did not exceed the standard for the content determined to be at a level of $400 \mathrm{mg} \mathrm{kg}^{-1}$ in fresh weight.

\subsection{Nitrite Content}

The average nitrite content for the 'Karotan' variety under study was $1.46 \mathrm{mg} \mathrm{kg}^{-1} \mathrm{FW}$ (Table 4). Ayaz et al. [28], Murawa et al. [33], Ziarati and Arbabi-Bidgoli [27] obtained nitrite contents of the roots at levels of $0.57,1.01$, and $0.65 \mathrm{mg} \mathrm{kg}^{-1} \mathrm{FW}$ but they provided no information on the varieties of the carrot in those studies. In our study, nitrites content after harvest and after storage was low in the control, Kelpak 1, Kelpak 2, and Asahi (Table 4). According to Przybysz et al. [21] and Wierzbowska et al. [15], reasonable soil fertilization combined with foliar feeding at appropriate stages, limit the accumulation of harmful compounds. Such effects of the preparations are related to the physiology of plants, which, properly stimulated, are able to reduce the intake of nitrates and harmful 
elements from the soil [53]. According to Colla et al. [13], biostimulants have the potential of preventing the high concentration of nitrates. This property could be attributed to the up-regulation of several metabolic pathways involved in nitrogen metabolism, in particular nitrite and nitrate reductase as well as glutamate synthase and glutamine synthetase activities.

Table 4. Nitrites content in carrot storage roots depending on the type and methods of biostimulant application and the time of storage, mean 2009-2011 ( $\left.\mathrm{mg} \mathrm{kg}^{-1} \mathrm{FW}\right)$.

\begin{tabular}{ccccc}
\hline Biostimulant & After Harvest & CV (\%) & After Storage & CV (\%) \\
\hline Control & $1.04 \pm 0.07 \mathrm{a}$ & 6.68 & $1.02 \pm 0.08 \mathrm{a}$ & 7.30 \\
Kelpak 1 & $1.30 \pm 0.06 \mathrm{abc}$ & 4.62 & $1.22 \pm 0.07 \mathrm{abc}$ & 6.65 \\
Kelpak 2 & $1.37 \pm 0.07 \mathrm{abc}$ & 4.85 & $1.28 \pm 0.11 \mathrm{abcd}$ & 8.90 \\
Kelpak 3 & $1.66 \pm 0.28 \mathrm{cde}$ & 17.00 & $1.57 \pm 0.32 \mathrm{bcd}$ & 20.18 \\
Kelpak 4 & $1.52 \pm 0.19 \mathrm{bcde}$ & 12.62 & $1.42 \pm 0.21 \mathrm{abcd}$ & 14.43 \\
Kelpak 5 & $1.79 \pm 0.09 \mathrm{e}$ & 4.97 & $1.65 \pm 0.19 \mathrm{~cd}$ & 11.78 \\
Kelpak 6 & $1.77 \pm 0.17 \mathrm{de}$ & 9.63 & $1.67 \pm 0.16 \mathrm{~d}$ & 9.76 \\
Kelpak 7 & $1.39 \pm 0.04 \mathrm{abcd}$ & 2.88 & $1.30 \pm 0.08 \mathrm{abcd}$ & 5.38 \\
Kelpak 8 & $1.48 \pm 0.07 \mathrm{bcde}$ & 4.49 & $1.43 \pm 0.09 \mathrm{abcd}$ & 5.18 \\
Asahi & $1.25 \pm 0.03 \mathrm{abc}$ & 2.36 & $1.18 \pm 0.06 \mathrm{ab}$ & 4.81 \\
\hline Total mean & $1.46 \pm 0.25$ & 17.47 & $1.37 \pm 0.24$ & 17.70 \\
Biostimulants mean & $1.50 \pm 0.22$ & 14.76 & $1.41 \pm 0.23$ & 15.77 \\
Kelpak mean & $1.53 \pm 0.21$ & 14.01 & $1.44 \pm 0.20$ & 15.15 \\
\hline
\end{tabular}

Means sharing the same letter in column are not significantly different from each other (Tukey's significant difference test, $\mathrm{P}<0.05)$. $\mathrm{CV}$ means the coefficients of variation. Data are presented as the means \pm standard deviations $(\mathrm{n}=18)$.

The calculated mean variation coefficients (CV) for nitrates and nitrites (Tables 3 and 4) indicate that for both compounds, immediately following the harvest and following storage at a constant temperature of $+1{ }^{\circ} \mathrm{C}$ and an air relative humidity of $95 \%$, greater variation was exhibited by the roots after the application of Kelpak biostimulant during the carrot growing period.

\subsection{Storage Effect}

In our study, regardless of the type and methods of biostimulant application, a decrease in the nitrate content in roots after six months of storage was found (Figures 1 and 2). Similar results were obtained by Wrzodak and Elkner [55], who reported that the nitrate content decreased by about 14-17\% in carrot roots after seven-month storage. Moreover, Gajewska et al. [56] found more nitrates in carrot in the autumn and winter period $\left(200 \mathrm{mg} \mathrm{kg}^{-1}\right)$ than in spring and summer $\left(185 \mathrm{mg} \mathrm{kg}^{-1}\right)$. In Figure 1, it is noted that following the storage, in the roots of carrot on which Asahi and Kelpak had been applied, a much greater decrease in nitrate content (mean 8\%) was obtained than in the control object (without the use of biostimulants). The reduction of nitrates content was significant as compared to the control after triple application of Kelpak in a total dose of $7 \mathrm{dm}^{3} \mathrm{ha}^{-1}$ (K5) or $5 \mathrm{dm}^{3} \mathrm{ha}^{-1}$ (K7). However, other results were obtained by Wierzbowska et al. [15] following the application of the Asahi during the growing of carrots because after five months, stored carrot roots increased nitrate content four-fold in roots from the integrated system and three-fold in ecological carrots. According to Wrona [57], nitrates are reduced to nitrites during the storage of vegetables. The process may intensify when the temperature during storage is higher than the recommended one $[27,58]$. The great decreases of nitrates obtained in our study prove that constant conditions were maintained throughout the entire storage period, in accordance with recommendations for root vegetables. What is more, similarly to nitrates, the six-month period of storage of the roots decreased nitrite content, which confirms the significant positive correlation coefficient between nitrates and nitrites $\left(\mathrm{r}=0.551 ; \mathrm{P}_{0.05}\right)$ (Figure 1$)$. 


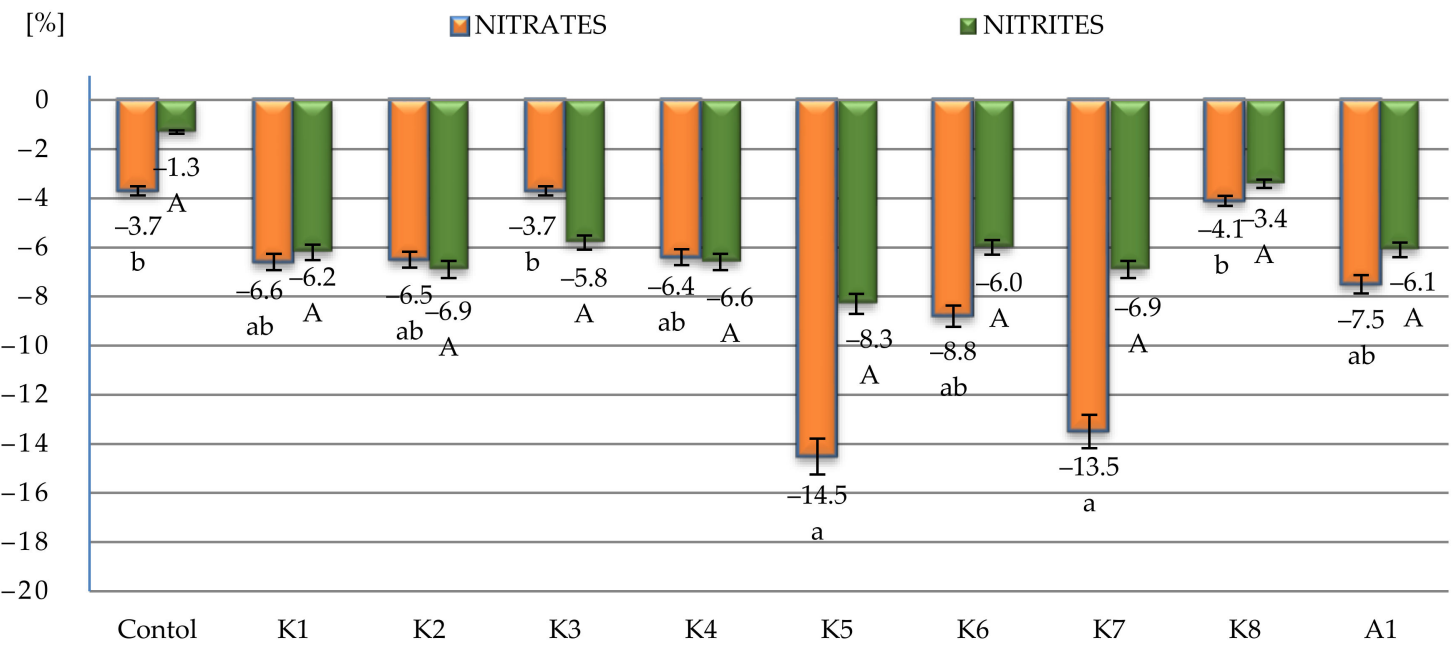

Figure 1. Percentage reduction of the content of anti-nutritive compounds in carrot roots after six-month storage period. Vertical bars show \pm SE of means $(n=18)$. Means sharing the same lowercase or uppercase letters for nitrates or nitrites, respectively are not significantly different from each other (Tukey's significant difference test, $\mathrm{P}<0.05$ ).

The decrease in nitrate content proved to be much greater in the roots originating from the cultivation with biostimulants applied (Figure 1). Opinions on the effects of storage on nitrate content of vegetables vary. According to Wierzbowska et al. [15], storage results in a significant increase in nitrate content and Marks [41] found that the effects of storage appeared to be insignificant. Wierzbowska et al. [15] found that after storage, the amount of nitrates increased four times in carrots originating from an integrated cultivation system and increased three times for carrots originating from an organic cultivation system. According to many authors [31,57,59], the most important factor affecting the quality of vegetables following storage are the conditions prevailing during storage.

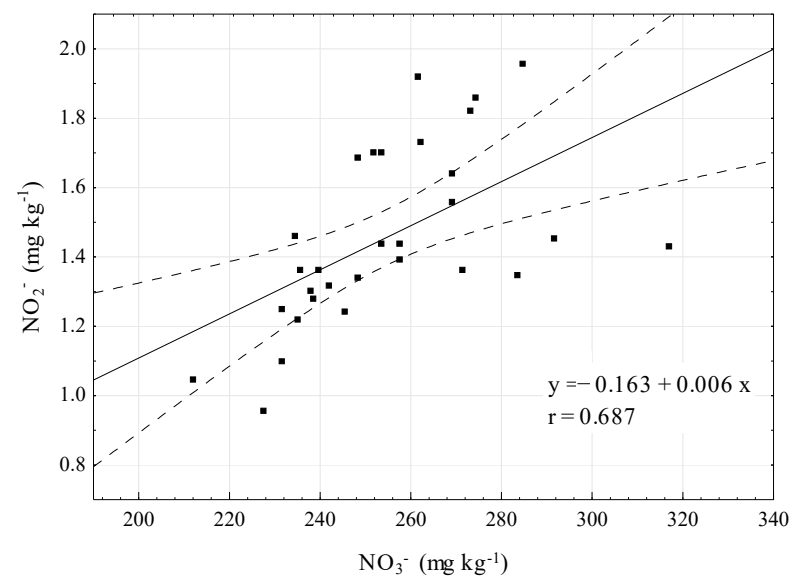

(a) after harvest

Figure 2. Cont. 


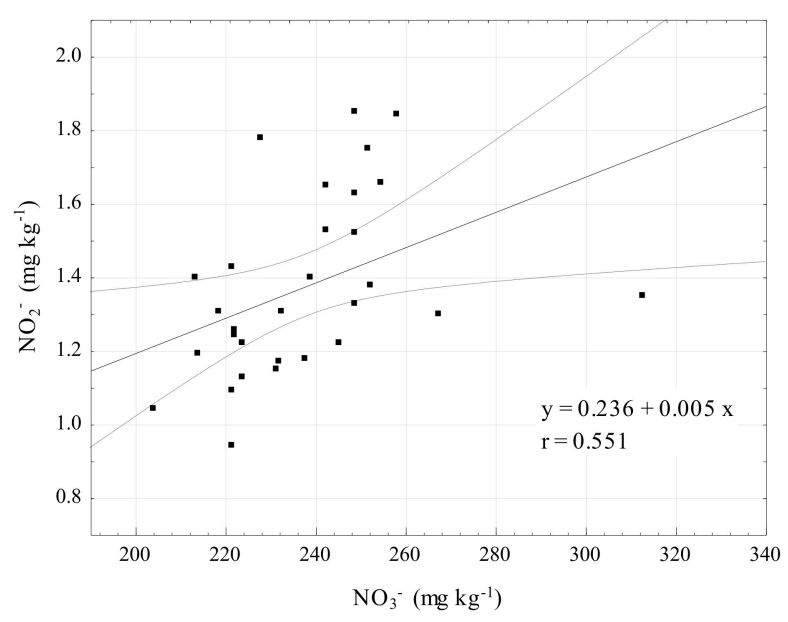

(b) after storage

Figure 2. The significant relationship between the nitrates and nitrites content in carrot roots: (a) directly after harvest, (b) after 6 months storage. $r$ indicates that the correlation is significant at the 0.05 probability level.

Gajewski et al. [49], having tested eight varieties, obtained an average reduction in nitrate content at a level of up to $22 \%$. It should be stressed, however, that for the 'Interceptor', 'Nebula', and 'White Satin' varieties after storage, an increase in the concentration of nitrates was noted: by $18.9 \%, 0.23 \%$ and $1.5 \%$, respectively. Wrona [57] stored carrots under industrial conditions and in a refrigerator and in both cases, obtained a reduction in nitrate content by $13 \%$ and $53 \%$, respectively. Such a large difference could have resulted from a higher storage temperature in the refrigerator than under industrial conditions.

\subsection{Daily Intake of Nitrates and Nitrites}

In our study, the maximum daily intake of nitrates following the harvest was $15.7 \mathrm{mg}$, and following the storage, it was $14.8 \mathrm{mg}$ (Table 5), which accounts for $7.1 \%$ and $6.7 \%$ of the ADI (acceptable daily intake). On the other hand, for nitrites, the maximum intake following the harvest and following storage amounted to 0.10 and $0.09 \mathrm{mg}$, respectively, which accounts for $2.3 \%$ and $2.1 \%$ of the ADI. Wszelaczyńska et al. [32], defined the daily intake of nitrates and nitrites introduced into the body with carrots for adults as 13.4 and $0.11 \mathrm{mg} \mathrm{day}^{-1}$, respectively. Similarly, as in the present research, they did not exceed the ADI norm. In comparison with the European Union norms, maximum $\mathrm{NO}_{3}{ }^{-}$ and $\mathrm{NO}_{2}{ }^{-}$levels were not exceeded [26,46].

Table 5. Daily intake of anti-nutritive compounds with the consumption of $55 \mathrm{~g}$ carrot roots depending on type and methods of biostimulant application and the time of storage, mean $2009-2011$ ( $\left.\mathrm{mg} \mathrm{kg}^{-1} \mathrm{FW}\right)$.

\begin{tabular}{ccccc}
\hline & \multicolumn{4}{c}{ Daily Intake (DI) } \\
\hline \multirow{2}{*}{ Biostimulant } & \multicolumn{2}{c}{ Nitrates } & \multicolumn{2}{c}{ Nitrites } \\
\cline { 2 - 5 } & After Harvest & After Storage & After Harvest & After Storage \\
\hline Control & 12.3 & 11.9 & 0.06 & 0.06 \\
Kelpak 1 & 13.3 & 12.4 & 0.07 & 0.07 \\
Kelpak 2 & 13.6 & 12.8 & 0.08 & 0.07 \\
Kelpak 3 & 13.8 & 13.3 & 0.09 & 0.09 \\
Kelpak 4 & 14.1 & 13.6 & 0.08 & 0.08 \\
Kelpak 5 & 15.7 & 14.8 & 0.10 & 0.09 \\
Kelpak 6 & 15.0 & 13.1 & 0.10 & 0.09 \\
Kelpak 7 & 14.8 & 13.6 & 0.08 & 0.07 \\
Kelpak 8 & 14.6 & 12.9 & 0.08 & 0.08 \\
Asahi & 12.9 & 12.4 & 0.07 & 0.06 \\
\hline
\end{tabular}


Grudzińska and Zgórska [47] noted that thermal processing reduced the nitrate content by up to $30 \%$. It is known that the largest amounts of nitrates in the carrot are found in the inner core. Therefore, the process of peeling may result in a slight increase in $\mathrm{NO}_{3}{ }^{-}$levels as the removal of the peel decreases the weight of the root, which increases the ratio of this component to the weight.

\section{Conclusions}

Nitrate and nitrite content in storage carrot roots after harvest depend on the dose and the date of biostimulant application. The single application of biostimulant Kelpak as well as two times of Asahi had no effect on the nitrate and nitrite content while the application of Kelpak in a total dose of 6 or $7 \mathrm{dm}^{3} \mathrm{ha}^{-1}$ increased them. For the safety of the roots of the tested variety as regards nitrate and nitrite contents, it appeared that a single application of the preparation Kelpak was the most advantageous. The storage resulted in a considerable reduction in the concentration of anti-nutritive compounds in the carrot roots. The tested cv. 'Karotan' did not exceed the standards for nitrate and nitrite contents in wet weight or ADI. However, it is not suitable for processed foods for children.

Author Contributions: Conceptualization, M.S., J.P. and E.W.; methodology, M.S., J.P. and E.W.; validation, M.S., J.P. and E.W.; formal analysis, M.S.; investigation, M.S., J.P. and E.W.; resources, M.S.; data curation, M.S., J.P. and E.W.; writing—original draft preparation, M.S., J.P., E.W., and P.P.; writing—review and editing, M.S., J.P., E.W., and P.P.; visualization, M.S., J.P. and P.P.; project administration, M.S.; All authors have read and agreed to the published version of the manuscript.

Funding: This research received no external funding.

Acknowledgments: The authors wish to thank the mediums and sitters who volunteered their time for this study. Publication carried out with the use of instruments bought in the framework of programme 'Development of Stage 2 of Regional Centre for Innovativeness' the European Fund for Regional Development in the framework of the Regional Operation Programme of Kuyavian-Pomeranian for 2007-2013.

Conflicts of Interest: The authors declare no conflict of interest.

\section{References}

1. Briglia, N.; Petrozza, A.; Hoeberichts, F.A.; Verhoef, N.; Povero, G. Investigating the Impact of Biostimulants on the Row Crops Corn and Soybean Using High-Efficiency Phenotyping and Next Generation Sequencing. Agronomy 2019, 9, 761. [CrossRef]

2. Colantoni, A.; Recchia, L.; Bernabei, G.; Cardarelli, M.; Rouphael, Y.; Colla, G. Analyzing the environmental impact of chemically-produced protein hydrolysate from leather waste vs. enzymatically-produced protein hydrolysate from legume grains. Agriculture 2017, 7, 62. [CrossRef]

3. D'Addabbo, T.; Laquale, S.; Perniola, M.; Candido, V. Biostimulants for Plant Growth Promotion and Sustainable Management of Phytoparasitic Nematodes in Vegetable Crops. Agronomy 2019, 9, 616. [CrossRef]

4. Di Mola, I.; Cozzolino, E.; Ottaiano, L.; Giordano, M.; Rouphael, Y.; Colla, G.; Mori, M. Effect of Vegetal-and Seaweed Extract-Based Biostimulants on Agronomical and Leaf Quality Traits of Plastic Tunnel-Grown Baby Lettuce under Four Regimes of Nitrogen Fertilization. Agronomy 2019, 9, 571. [CrossRef]

5. Lin, K.H.; Lin, F.W.; Wu, C.W.; Chang, Y.S. Biostimulation of Maize (Zea mays) and Irrigation Management Improved Crop Growth and Water Use under Controlled Environment. Agronomy 2019, 9, 559. [CrossRef]

6. Sandepogu, M.; Shukla, P.S.; Asiedu, S.; Yurgel, S.; Prithiviraj, B. Combination of Ascophyllum nodosum Extract and Humic Acid Improve Early Growth and Reduces Post-Harvest Loss of Lettuce and Spinach. Agriculture 2019, 9, 240. [CrossRef]

7. EU. Regulation (EU) 2019/1009 of the European Parliament and of the Council of 5 June 2019 laying down rules on the making available on the market of EU fertilising products and amending Regulations (EC) No 1069/2009 and (EC) No 1107/2009 and repealing Regulation (EC) No 2003/2003. Off. J. Eur. Union 2019, L 170.

8. Kowalska, M.; Knapik, W.; Bogusz, M. Farm Education as a Component of Sustainable Development in Selected Countries of the European Union. Probl. Ekorozwoju Probl. Sustain. Dev. 2016, 11, 81-88.

9. Ntshangase, N.; Muroyiwa, B.; Sibanda, M. Farmers' perceptions and factors influencing the adoption of no-till conservation agriculture by small-scale farmers in Zashuke, KwaZulu-Natal Province. Sustainability 2018, 10, 555. [CrossRef] 
10. Prus, P. Sustainable Farming Production and its Impact on the Natural Environment-Case Study Based on a Selected Group of Farmers. In Proceedings of the 8th International Scientific Conference RURAL Development, Kaunas, Lithuania, 23-24 November 2017; pp. 1280-1285. [CrossRef]

11. Prus, P.; Drzazdzynska, K. Farmers' assessment of training services and the impact of agricultural advisory on selected developmental factors affecting farming. In Proceedings of the International Conference Economic Science for Rural Development, Jelgava, Latvia, 27-28 April 2017; p. 338, No 44.

12. Fortune Business Insights. Biostimulant Market Size, Share and Industry Analysis by Source (Microbial and Non-Microbial), by Active Ingredients (Seaweed Extracts, Humic Substances, Vitamins \& Amino Acids, Microbial Amendments, and Others), by Application (Foliar Treatment, Soil Treatment, and Seed Treatment), by Crop (Row Crops, Fruits E Vegetables, Turf E Ornamentals), and Regional Forecast 2019-2026; Report ID:FB/100414; Fortune Business Insights: Pune, Maharashtra, India, 2019.

13. Colla, G.; Hoagland, L.; Ruzzi, M.; Cardarelli, M.; Bonini, P.; Canaguier, R.; Rouphael, Y. Biostimulant action of protein hydrolysates, unravelling their effects on plant physiology and microbiome. Front. Plant Sci. 2017, 8, 2202. [CrossRef]

14. Grabowska, A.; Kunicki, E.; Sękara, A.; Kalisz, A.; Wojciechowska, R. The effect of cultivar and biostimulant treatment on the carrot yield and its quality. Veg. Crops Res. Bull. 2012, 77, 37-48. [CrossRef]

15. Wierzbowska, J.; Cwalina-Ambroziak, B.; Głosek-Sobieraj, M.; Sienkiewicz, S. Yield and mineral content of edible carrot depending on cultivation and plant protection methods. Acta Sci. Pol. Hortorum Cultus 2017, 16, 75-86.

16. Sekoli, M.M.S.; Pretorius, J.C.; Coetzer, G.M. Sugar and B-carotene accumulation in carrot (Daucus Carota, L.) tap roots as influenced by fertilization and biostimulant application under greenhouse conditions. Glob. J. Agric. Res. 2016, 4, 18-31.

17. Rouphael, Y.; Colla, G. Synergistic biostimulatory action: Designing the next generation of plant biostimulants for sustainable agriculture. Front. Plant Sci. 2018, 9, 1655. [CrossRef]

18. Jannin, L.; Arkoun, M.; Etienne, P.; Laine, P.; Goux, D.; Garnica, M.; Fuentes, M.; San Francisco, S.; Baigorri, R.; Cruz, F.; et al. Brassica napus growth is promoted by Ascophyllum nodosum (L.) Le Jol. seaweed extract: Microarray analysis and physiological characterization of N, C, and S metabolisms. J. Plant Growth Regul. 2013, 32, 31-52. [CrossRef]

19. Nair, P.; Kandasamy, S.; Zhang, J.; Ji, X.; Kirby, C.; Benkel, B.; Hodges, M.D.; Critchley, A.T.; Hiltz, D.; Prithiviraj, B. Transcriptional and metabolomic analysis of Ascophyllum nodosum mediated freezing tolerance in Arabidopsis thaliana. BMC Genom. 2012, 13, 643. [CrossRef]

20. Szczepanek, M.; Wszelaczyńska, E.; Pobereżny, J.; Ochmian, I. Response of onion (Allium cepa L.) to the method of seaweed biostimulant application. Acta Sci. Pol. Hortorum Cultus 2017, 16, 113-122.

21. Przybysz, A.; Gawrońska, H.; Gajc-Wolska, J. Biological mode of action of a nitrophenolates-based biostimulant: Case study. Front. Plant Sci. 2014, 5, 713. [CrossRef]

22. Kocira, S.; Szparaga, A.; Kuboń, M.; Czerwińska, E.; Piskier, T. Morphological and biochemical responses of Glycine max (L.) Merr. to the use of seaweed extract. Agronomy 2019, 9, 93. [CrossRef]

23. Szczepanek, M.; Wilczewski, E.; Pobereżny, J.; Wszelaczyńska, E.; Ochmian, I. Carrot root size distribution in response to biostimulant application. Acta Agric. Scand. Sect. B Soil Plant Sci. 2017, 67, 334-339. [CrossRef]

24. Wszelaczyńska, E.; Szczepanek, M.; Pobereżny, J.; Kazula, M. Effect of biostimulant application and long-term storage on the nutritional value of carrot. Hortic. Bras. 2019, 37, 451-457. [CrossRef]

25. Hager, T.J.; Howard, L.R. Processing effects on carrot phytonutrients. HortScience 2006, 41, 74-79. [CrossRef]

26. Sušin, J.; Kmecl, V.; Gregorčič, A. A survey of nitrate and nitrite content of fruit and vegetables grown in Slovenia during 1996-2002. Food Addit. Contam. 2006, 23, 385-390. [CrossRef] [PubMed]

27. Ziarati, P.; Arbabi-Bidgoli, S. Investigation of cooking method on nitrate and nitrite contents in crops and vegetables and assess the associated health risk. Int. J. Plant Anim. Environ. Sci. 2014, 4, 46-52.

28. Ayaz, A.; Topcu, A.; Yurdagul, M. Survey of nitrate and nitrite levels of fresh vegetables in Turkey. J. Food Technol. 2007, 5, 177-179.

29. Karkleliene, R.; Radzevičius, A.; Bobinas, Č. Productivity and root-crop quality of Lithuanian carrot (Daucus sativus Rőhl.) Breeder lines. Proc. Latv. Acad. Sci. Sect. B 2009, 63, 63-65. [CrossRef]

30. Kramer, M.; Maksymowicz-Kauna, A.; Baranski, R.; Nothnagel, T.; Carle, R.; Kammerer, D.R. Effects of cultivation year and growing location on the phenolic profile of differently coloured carrot cultivars. J. Appl. Bot. Food Qual. 2012, 85, 235-247. 
31. Tietze, M.; Burghardt, A.; Bragiel, P.; Mac, J. Content of nitrosamines in foodstuff. Ann. Univ. Lub. 2007, $25,71-77$.

32. Wszelaczyńska, E.; Pobereżny, J.; Keutgen, A. Effect of genetic conditions, foliar fertilisation with magnesium and storage on the content of nitrates (V) and (III) in the storage roots in carrot. Environ. Prot. Nat. Res. 2014, 25, 7-11. [CrossRef]

33. Murawa, D.; Banaszkiewicz, B.; Majewska, E.; Błaszczuk, B.; Sulima, J. Nitrate and nitrite content in selected vegetables and potatoes commercially available in Olsztyn. Bromatol. Chem. Toksykol. 2008, 41, 67-71.

34. Santamaria, P. Nitrate in vegetables: Toxicity, content, intake and EC regulation. J. Sci. Food Agric. 2005, 86, 10-17. [CrossRef]

35. Gajewski, M.; Weglarz, Z.; Baker, M.; Kuczkowska, A.; Majewski, M.; Woreda, A. Quality of carrots grown for processing as affected by nitrogen fertilization and harvest term. Veg. Crops Res. Bull. 2009, 70, 135-144. [CrossRef]

36. Burlingame, B.; Pineiro, M. The essential balance: Risks and benefits in food safety and quality. J. Food Compos. Anal. 2007, 20, 139-146. [CrossRef]

37. Larsen, J. Risk assessment of chemicals in European traditional foods. Trends Food Sci. Techol. 2006, 17, 471-481. [CrossRef]

38. Łozowicka, B. Chemical contaminants in plant food. Prog. Plant Prot. 2009, 49, 2071-2080.

39. Commission Regulation (EU) No 1258/2011 of 2 December 2011 amending Regulation (EC) No 1881/2006 as regards maximum levels for nitrates in foodstuffs. Off. J. Eur. Union 2011, L 320/15.

40. Bottex, B.; Dorne, J.L.C.M.; Carlander, D.; Benford, D.; Przyrembel, H.; Heppnera, C.; Kleinera, J.; Cockburnc, A. Risk-Benefit health assessment of food-Food fortification and nitrate in vegetables. Trends Food Sci. Techol. 2008, 19, 113-119. [CrossRef]

41. Marks, N. Content of nitrates, nitrites and heavy metals in potato tubers depending on their storage period duration. Inżynieria Rolnicza 2009, 1, 183-187.

42. Machha, A.; Schechter, A.N. Inorganic nitrate: A major player in the cardiovascular health benefits of vegetables? Nutr. Rev. 2012, 70, 367-372. [CrossRef]

43. Szczepanek, M.; Siwik-Ziomek, A. P and K accumulation by rapeseed as affected by biostimulant under different NPK and S fertilization doses. Agronomy 2019, 9, 477. [CrossRef]

44. Czeczko, R.; Mikos-Bielak, M. Effects of Asahi bio-stimulator application in the cultivation of different vegetable species. Ann. UMCS Agric. 2004, 59, 1073-1079.

45. Baker, W.H.; Thompson, T.L. Determination of nitrate-nitrogen (NO3-N) in plant samples by selective ion electrode. In "Plant Analysis Reference Procedures for the Southern Region of the United States- Southern Cooperative Series Bulletin \#368"; The University of Georgia: Athens, GA, USA, 1992; pp. 23-26.

46. Burt, T.P.; Heathwaite, A.L.; Trudgill, S.T. Nitrate: Process, Pattern and Management; Wiley: Chichester, UK, 1993; pp. 10-28.

47. Grudzińska, M.; Zgórska, K. Effect of preliminary and thermal processing on the content of nitrate in vegetables. Rocz. Ochr. Środ. 2005, 7, 233-241.

48. Bender, I.; Ess, M.; Matt, D.; Moor, U.; Tõnutare, T.; Luik, A. Quality of organic and conventional carrots. Agron. Res. 2009, 7, 572-577.

49. Gajewski, M.; Szymczak, P.; Bajer, M. The accumulation of chemical compounds in storage roots by carrots of different cultivars during vegetation period. Acta Sci. Pol. Hortorum Cultus 2009, 8, 69-78.

50. Anyszka, Z.; Ekner, K. The influence of some herbicides on yield and chemical composition of baby carrots. Roczniki AR w Poznaniu 2007, 383, 417-420.

51. Dobrzański, A.; Anyszka, Z.; Elkner, K. Response of carrots to application of natural extracts from seaweed (sargassum sp.)—Algaminoplant and from leonardite-Humiplant. J. Res. Appl. Agric. Eng 2008, 53, 53-58.

52. Szczepanek, M.; Wilczewski, E.; Pobereżny, J.; Wszelaczyńska, E.; Keutgen, A.; Ochmian, I. Effect of biostimulants and storage on microelement content in storage roots of carrot. J. Elem. 2015, 20, 1021-1031. [CrossRef]

53. Smoleń, S.; Sady, W.; Ledwożyw-Smoleń, I.; Strzetelski, P.; Liszka-Skoczylas, M.; Rożek, S. Quality of fresh and stored carrots depending on iodine and nitrogen fertilization. Food Chem. 2014, 159, 316-322. [CrossRef] [PubMed] 
54. Kwiatkowski, C.A.; Haliniarz, M.; Kołodziej, B.; Harasim, E.; Tomczyńska-Mleko, M. Content of some chemical components in carrot (Daucus carota L.) roots depending on growth stimulators and stubble crops. J. Elem. 2015, 20, 933-943. [CrossRef]

55. Wrzodak, A.; Elkner, K. Sensory quality of fresh and stored carrots from organic farming. Veg. Crops Res. Bull. 2010, 50, 93-101.

56. Gajewska, M.; Czajkowska, A.; Bartodziejska, B. The content of nitrates (III) and (V) in selected vegetables on detail sale in Lodz region. Environ. Prot. Nat. Res. 2009, 40, 388-395.

57. Wrona, P. Quality changes of carrot which occur during storing. Agric. Eng. 2012, 2, 337-345.

58. Amr, A.; Hadidi, N. Effect of cultivar and harvest date on nitrate $\left(\mathrm{NO}_{3}\right)$ and nitrite $\left(\mathrm{NO}_{2}\right)$ content of selected vegetables grown under open field and greenhouse conditions in Jordan. J. Food Compos. Anal. 2001, 14, 59-67. [CrossRef]

59. Pobereżny, J.; Wszelaczyńska, E.; Wichrowska, D.; Jaskulski, D. Content of nitrates in potato tubers depending on the organic matter, soil fertilizer, cultivation simplifications applied and storage. Chil. J. Agric. Res. 2015, 75, 42-49. [CrossRef]

(C) 2020 by the authors. Licensee MDPI, Basel, Switzerland. This article is an open access article distributed under the terms and conditions of the Creative Commons Attribution (CC BY) license (http://creativecommons.org/licenses/by/4.0/). 